\title{
Effects of stress coping and emotion regulation on student academic stress
}

\author{
Permata Sari, Siti Zahra Bulantika, Tri Dewantari, Rubi Rimonda
}

\author{
Universitas Islam Negeri Raden Intan Lampung, Indonesia \\ permataonte193@gmail.com
}

Submitted : 2020-04-22, Revised : 2020-05-14, Accepted : 2020-05-22

\begin{abstract}
This study aims to determine the effect of stress coping and emotion regulation on student academic stress. This study is an expos facto study with a sample of semester IV Islamic counseling guidance students of UIN Raden Intan Lampung, as many as 150 students, samples taken by the purposive method. The instruments used in this study were stress coping scale, emotion regulation scale, and academic stress scale, which had been developed based on indicators and had been validated. The analysis used in this study is the multiple regression analysis. The results of the study indicate that stress coping and emotional regulation have a significant effect on student academic stress.
\end{abstract}

Keywords: academic stress, emotion regulation, stress coping

\section{Introduction}

Students are future leaders, and they are expected to have academic success as their primary goal. High education, quality, and satisfying results are the great expectations of all students. But sometimes, the many academic demands cause students to experience academic stress. Academic stress is a condition or condition where there is a mismatch between environmental needs and the actual resources owned by students so that various pressures and demands increasingly burden them (Crego et al., 2016). Academic stress arises because of pressures to show achievement and excellence in conditions of increasing academic competition so that various pressures and demands increasingly burden them (Neseliler et al., 2017).

A study says that academic stress will have an adverse impact, because it can result in the emergence of various other problems, both in terms of a person's physical, emotional, and cognitive (Barker et al., 2018). Furthermore, academic stress will affect everything in student life related to academics, and academic stress will be a mental stress associated with frustration and cause academic failure (Reddy et al., 2018). Also, responses to academic stress, often seen from a mental disorder, inability to concentrate, feelings of fear, anxiety, shame, anger, depression, and denial (Karaman \& Watson, 2017).

The phenomenon that exists in the field at this time, many students are exposed to academic stress. With all the demands, pressures related to competition, deadlines, excessive workloads causing conflicts on students, the existence of this phenomenon will hurt students.

Several factors cause students to stress in academics, both from external factors and internal factors. From external factors, namely, the curriculum in the education system is increasingly higher standard. As a result, competition is getting tighter, learning time is increasing, and student burdens are growing. Although reasons are essential for the development of education in the country, it cannot close eyes that it increases the stress levels 
faced by students, the pressure to achieve high or get satisfactory grades, students are immensely pressured to perform well in their examinations (Ramli et al., 2018).

This pressure mainly comes from parents, family, teachers, neighbors, peers, and yourself. Furthermore, the thing that influences, namely education, becomes a symbol of social status. The public will respect people with high academic qualifications, and those who are not highly educated will be looked down on (Ramachandiran \& Dhanapal, 2018). Academically successful students are well-liked, well-known, and praised by the public. Conversely, students who have low grades do not excel are called slow, lazy, or painful, and that will cause anxiety for students.

Furthermore, it is not only external factors that affect student academic stress, and several internal factors can affect student academic stress namely thought patterns, personalities, and beliefs (Azmy et al., 2017). In these three points, there is stress coping and emotional regulation, which are the source in controlling students facing academic stress. Stress coping is a form of self-adjustment that involves elements of cognition and affection from a person to overcome the problems that come to him (Jamal et al., 2017). Stress coping used by students also affects the level of individual assertiveness. The effect of the environment can be pressure on individuals. The response or reaction from individuals to get out of this pressure is called coping.

The coping strategy will be able to influence someone who has the skills in dealing with academic demands on him or not. One of the results of the research that reinforces the above statement states that students who succeed in academia are students who have right coping strategies in this case students have the adjustment made by individuals to protect themselves in circumstances that threaten their existence in a problem being faced (Fares et al., 2016).

Furthermore, other studies have found that students who have right coping strategies can manage, solve, or even reduce external and internal demands and pressure in a conflict so that the individual can survive in conditions that make him under pressure or stress (Sitepu \& Nasution, 2017). Another factor that influences academic stress is emotion regulation. Emotion regulation is a strategy carried out consciously or unconsciously to maintain, strengthen, or reduce one or more aspects of emotional responses, namely the experience of emotions and behavior. Emotion regulation is a form of representational results of the development process (Roth et al., 2019). This is supported by research that found engineering students feel well-being and happiness because they have high emotion regulation; students can maintain and enhance emotions that they think are positive (Alfinuha \& Nuqul, 2017). Furthermore, other studies have found that the ability of each individual's emotional regulation varies based on emotional experience and behavior (Pahlevi \& Salve, 2019).

Based on this, it can be described that emotion regulation is an emotion that is an emotional control that is in students to deal with an external stimulus. Emotion regulation is the process of receiving, maintaining, and controlling events, the intensity and duration of emotions felt, physiological processes related to emotions, facial expressions, and observable behavior. Emotion regulation cannot be separated from human life. Mindfulness or cognitive processes help individuals regulate emotions or feelings and keep those emotions from being excessive. Therefore, the habit of students mastering negative emotions can make them able to control emotions in many situations. 
Some of the above descriptions are of interest to researchers to deepen in terms of scientific guidance and counseling related to student academic stress. In this case, the researcher wants to see the effect of stress coping and emotion regulation on student academic stress. The hope is that if emotion regulation and stress coping are proven to have a positive impact on academic stress, then this can be used as a direction for counselors always to maintain and develop emotion regulation and stress coping to reduce academic stress on students through guidance and counseling.

\section{Method}

This research is an ex post facto research that aims to determine the effect of stress coping and emotion regulation on student academic stress. The sample in this study was 150 students of Islamic guidance and counseling study program. The method of sample collection uses a purposive method. The instruments in this study were stress coping scales, emotion regulation scales, and academic stress scales developed based on each indicator. Data analysis in this study used multiple regression analysis, which previously fulfilled assumptions in multiple regression, namely the normality test, the multicollinearity assumption test, the heteroskedasticity assumption test, and autocorrelation.

\section{Results and Discussion}

The results of multiple linear regression calculations are used to predict the magnitude of the relationship between the dependent variable, academic stress (Y) and the independent variable, stress coping (X1) and emotion regulation (X2). The results of these calculations are shown in Table 1:

Table 1. Results of Multiple Linear Regression Tests

\begin{tabular}{lcccc}
\hline Independent variable & Regression Coefficient & t count & Sig. t & Information \\
\hline A constant & 33.433 & 122.613 & 0.000 & Significance \\
\hline Stres coping (X1) & -0.056 & -15.989 & 0.000 & Significance \\
\hline Emotion reguation $(\mathrm{X} 2)$ & -0.005 & -9.571 & 0.000 & Significance \\
\hline F count & $=283.695$ & & & \\
\hline R-square & $=0.656$ & & & \\
\hline
\end{tabular}

The dependent variable on the results of multiple regression tests is academic stress $(\mathrm{Y})$, while the independent variable is stress coping (X1) and emotion regulation (X2). The regression model based on the results of the analysis above is $\mathrm{Y}=33,433-0,056 \mathrm{X} 1-0,005$ $\mathrm{X} 2+\mathrm{e}$.

From the results of the multiple linear regression equation, it can be seen that the coefficient of regression in the regression is 33.433. The positive coefficient indicates that if there is no stress coping variable (X1), and emotion regulation (X2) then academic stress (Y) will increase by 33.433 or in other words, it can be interpreted that the value of 33.433 is the value when the stress-coping variable (X1), and emotional regulation (X2) constant. The stress coping regression coefficient (X1) is 0.056 , and the negative coefficient regression coefficient explains that if stress coping (X1) has increased by 1 unit the academic stress (Y) will decrease by 0.056 units with other conditions constant. 
The regression coefficient of emotional regulation (X2) of 0.005 and the regression coefficient of negative value explains that if an increase in emotion regulation (X2) of 1 unit, then academic stress (Y) will decrease by 0.005 units with other conditions constant. So it can be concluded that the stress-coping variable (X1) and emotion regulation (X2) has a significant effect together on student academic stress.

Academic stress on students is a condition or condition of individuals who experience pressure due to students' perceptions of educational activities related to science and education, caused by academic stressors (Sayekti, 2017). The stress response shown to each individual is different; this is determined by the ability to adapt to the changes that occur. Environmental conditions, changing habits and lack of individual ability to adjust can cause stress on the individual (Handono \& Bashori, 2013). In line with this opinion, the level of stress on students can occur due to several factors namely academic demands that are too heavy, results of tests that are not good, assignments that pile up, and social environment (Barseli et al., 2017). Based on this, decreasing or increasing stress on an individual is influenced by the ability of the individual to cope and having proper emotion regulation.

Emotions are often beneficial to students, and feelings can direct attention to learning goals, manage decision making when stressed, respond to behaviors ready to work and think and facilitate social interaction. However, emotions can also be dangerous, especially when emotions with excessive intensity, or the wrong duration for specific situations; this will trigger a state of learning stress or academic stress on students. At such times, students must try to regulate their emotions to modify the generative processes of emotions (Gross et al., 2011). Someone who regulates their emotions describes efforts to reduce negative emotions by reducing emotions that will trigger stress relapses such as anger, sadness, and anxiety (Gross et al., 2006), increase positive emotions. That is because emotional regulation has a relationship between decreased academic stress and mental health problems.

According to Greenberg \& Stone, emotion regulation can influence the reduction of student stress because this is the regulation of emotions is the ability of individuals to express their feelings both verbally and in writing. By showing their feelings, the individual can help improve health, psychological and physical well-being of the individual when facing traumatic events in his life, and help overcome mental stress (Mawardah \& Adiyanti, 2014). Proper emotion regulation provides a significant impact in mastering the expression of sadness or difficulties related to stress (Zhang et al., 2016). The better the emotion regulation an individual has, the less stress the individual experiences. The reduced level of stress experienced by students can be seen from the emergence of aspects of emotional regulation in the individual. The elements of emotion regulation, namely being able to regulate emotions, being able to control emotions, being able to manage the stress of the problem at hand (Sari $\&$ Hayati, 2015). To support the success of emotion regulation, several factors influence, namely, communication with family, openness, and social support from the surrounding environment. (Sari \& Hayati, 2015).

Based on research, results also decreased academic stress, which is influenced by stress coping. Coping is an individual effort to deal with threats and emotional consequences (Baron et al., 2009), controlling for discrepancies between the demands of an urgent situation and their ability to meet these demands, assessment is essential for businesses to manage a critical condition. Assessing events as challenges can result in coping efforts that are full of 
confidence and positive emotions while treating stressors as a threat can reduce selfconfidence in coping and cause negative emotions (Sears et al., 2009). Someone who uses reassessment expresses more positive emotions and fewer negative emotions, including fewer symptoms of stress (Gross \& John, 2003; Nezlek \& Kuppens, 2008). Individual coping can be effective or ineffective. Effective coping can produce new, permanent habits, whereas ineffective coping will produce new behaviors that deviate from the individual (Lubis et al., 2015). Coping success depends on coping resources (Sears et al., 2009).

The coping process is not a single event but involves ongoing relationship transactions with the environment, so it becomes a dynamic process, forming a reassessment that can be directed at altering the meaning of events or increasing personal understanding. The reassessment process will eventually lead to improved coping. To realize the success of coping, some factors support the implementation of stress coping, namely, there are internal factors and external factors. Internal factors, namely, cognitive factors, in this case, are selfefficacy, personality characteristics, and open heart attitude. Meanwhile, external factors from outside the individual are social support factors, positive reinforcement and pressure from the surrounding environment (Rizky \& Zulharman, 2014).

\section{Conclusions and Suggestions}

Based on the presentation of the results and discussion, it can be concluded that stress coping and emotion regulation has a significant influence on student academic stress. Further researchers should examine effective techniques or services to reduce academic stress or services and procedures that can improve students' abilities in coping with stress and emotional regulation. Counselors can provide services that help students to manage emotions and academic stress experienced.

\section{References}

Alfinuha, S., \& Nuqul, F. L. (2017). Bahagia dalam meraih cita-cita: Kesejahteraan subjektif mahasiswa teknik arsitektur ditinjau dari regulasi emosi dan efikasi diri. Psikohumaniora: Jurnal Penelitian Psikologi, 2(1), 12-28.

Azmy, A. N., Nurihsan, A. J., \& Yudha, E. S. (2017). Deskripsi gejala stres akademik dan kecenderungan pilihan strategi koping siswa berbakat. Indonesian Journal of Educational Counseling, 1(2), 197-208.

Barker, E. T., Howard, A. L., Villemaire-Krajden, R., \& Galambos, N. L. (2018). The rise and fall of depressive symptoms and academic stress in two samples of university students. Journal of Youth and Adolescence, 47(6), 1252-1266.

Baron, R. A., Branscombe, N. R., \& Byrne, D. (2009). So Boston. Pearson Education Inc.

Barseli, M., Ifdil, I., \& Nikmarijal, N. (2017). Konsep stres akademik siswa. Jurnal Konseling Dan Pendidikan, 5(3), 143-148.

Crego, A., Carrillo-Diaz, M., Armfield, J. M., \& Romero, M. (2016). Stress and academic performance in dental students: the role of coping strategies and examination-related self-efficacy. Journal of Dental Education, 80(2), 165-172.

Fares, J., Al Tabosh, H., Saadeddin, Z., El Mouhayyar, C., \& Aridi, H. (2016). Stress, burnout and coping strategies in preclinical medical students. North American Journal of Medical Sciences, 8(2), 75. 
Gross, J. J., \& John, O. P. (2003). Individual differences in two emotion regulation processes: implications for affect, relationships, and well-being. Journal of Personality and Social Psychology, 85(2), 348.

Gross, J. J., Richards, J. M., \& John, O. P. (2006). Emotion regulation in everyday life.

Gross, J. J., Sheppes, G., \& Urry, H. L. (2011). Emotion generation and emotion regulation: A distinction we should make (carefully). Cognition and Emotion (Print), 25(5), 765781.

Handono, O. T., \& Bashori, K. (2013). Hubungan antara penyesuaian diri dan dukungan sosial terhadap stres lingkungan pada santri baru. Empathy, 1(2), 79-89.

Jamal, Y., Zahra, S. T., Yaseen, F., \& Nasreen, M. (2017). Coping strategies and hardiness as predictors of stress among rescue workers. Pakistan Journal of Psychological Research, 32(1).

Karaman, M. A., \& Watson, J. C. (2017). Examining associations among achievement motivation, locus of control, academic stress, and life satisfaction: A comparison of US and international undergraduate students. Personality and Individual Differences, 111, $106-110$.

Lieberman, M. D., Inagaki, T. K., Tabibnia, G., \& Crockett, M. J. (2011). Subjective responses to emotional stimuli during labeling, reappraisal, and distraction. Emotion, $11(3), 468$.

Lubis, R., Irma, N. H., Wulandari, R., Siregar, K., Tanjung, N. A., Wati, T. A., \& Syahfitri, D. (2015). Coping stress pada mahasiswa yang bekerja. Jurnal Diversita, 1(2).

Mawardah, M., \& Adiyanti, M. G. (2014). Regulasi emosi dan kelompok teman sebaya pelaku cyberbullying. Jurnal Psikologi, 41(1), 60-73.

Neseliler, S., Tannenbaum, B., Zacchia, M., Larcher, K., Coulter, K., Lamarche, M., Marliss, E. B., Pruessner, J., \& Dagher, A. (2017). Academic stress and personality interact to increase the neural response to high-calorie food cues. Appetite, 116, 306-314.

Nezlek, J. B., \& Kuppens, P. (2008). Regulating positive and negative emotions in daily life. Journal of Personality, 76(3), 561-580.

Pahlevi, G. R., \& Salve, H. R. (2019). Regulasi emosi dan resiliensi pada mahasiswa merantau yang tinggal di tempat kos. Jurnal Psikologi, 11(2), 180-189.

Ramachandiran, M., \& Dhanapal, S. (2018). Academic stress among university students: A quantitative study of generation Y and Z's perception. Pertanika Journal of Social Sciences \& Humanities, 26(3).

Ramli, H., Hamizah, N., Alavi, M., Mehrinezhad, S. A., \& Ahmadi, A. (2018). Academic stress and self-regulation among university students in Malaysia: Mediator role of mindfulness. Behavioral Sciences, 8(1), 12.

Ray, R. D., McRae, K., Ochsner, K. N., \& Gross, J. J. (2010). Cognitive reappraisal of negative affect: Converging evidence from EMG and self-report. Emotion, 10(4), 587.

Reddy, K. J., Menon, K. R., \& Thattil, A. (2018). Academic stress and its sources among University students. Biomedical and Pharmacology Journal, 11(1), 531-537.

Rizky, E., \& Zulharman, Z. (2014). Hubungan efikasi diri dengan coping stress pada mahasiswa angkatan 2012 fakultas kedokteran Universitas Riau. Riau University.

Roth, G., Vansteenkiste, M., \& Ryan, R. M. (2019). Integrative emotion regulation: Process 
and development from a self-determination theory perspective. Development and Psychopathology, 31(3), 945-956.

Sari, M. D. I., \& Hayati, E. N. (2015). Regulasi emosi pada penderita HIV/AIDS. Empathy, 3(1), 23-30.

Sayekti, E. (2017). Efektifitas teknik self-instruction dalam mereduksi stress akademik pada siswa kelas XI MA YAROBI Kec. Grobogan, Kab. Grobogan Tahun 2016/2017. IAIN Salatiga.

Sears, D. O., Peplau, L. A., \& Taylor, S. E. (2009). Psikologi sosial (edisi ke dua belas). Jakarta: Kencana Prenada Media Group.

Sitepu, J. M., \& Nasution, M. (2017). Pengaruh konsep diri terhadap coping stress pada mahasiswa FAI UMSU. Intiqad: Jurnal Agama Dan Pendidikan Islam, 9(1), 68-83.

Wolgast, M., Lundh, L.-G., \& Viborg, G. (2011). Cognitive reappraisal and acceptance: An experimental comparison of two emotion regulation strategies. Behaviour Research and Therapy, 49(12), 858-866.

Zhang, M., Xv, G., Luo, C., Meng, D., \& Ji, Y. (2016). Qigong Yi Jinjing promotes pulmonary function, physical activity, quality of life and emotion regulation selfefficacy in patients with chronic obstructive pulmonary disease: A pilot study. The Journal of Alternative and Complementary Medicine, 22(10), 810-817. 